Review

\title{
Environmental Impact of Sulfate-Reducing Bacteria, Their Role in Intestinal Bowel Diseases, and Possible Control by Bacteriophages
}

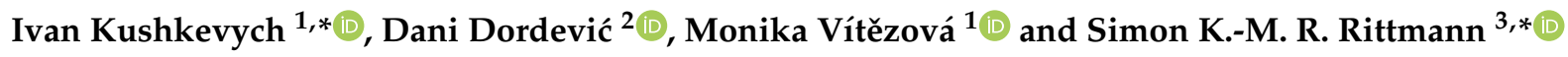 \\ 1 Department of Experimental Biology, Faculty of Science, Masaryk University, Kamenice 753/5, \\ 62500 Brno, Czech Republic; vitezova@sci.muni.cz \\ 2 Department of Plant Origin Foodstuffs Hygiene and Technology, Faculty of Veterinary Hygiene and Ecology, \\ University of Veterinary and Pharmaceutical Sciences, 61242 Brno, Czech Republic; dordevicd@vfu.cz \\ 3 Archaea Physiology \& Biotechnology Group, Department of Functional and Evolutionary Ecology, \\ Universität Wien, Althanstraße 14, 1090 Vienna, Austria \\ * Correspondence: kushkevych@mail.muni.cz (I.K.); simon.rittmann@univie.ac.at (S.K.-M.R.R.); \\ Tel.: +420-549-495-315 (I.K.); +431-427-776-513 (S.K.-M.R.R.)
}

check for

updates

Citation: Kushkevych, I.; Dordević, D.; Vítězová, M.; Rittmann, S.K.R.

Environmental Impact of

Sulfate-Reducing Bacteria, Their Role in Intestinal Bowel Diseases, and Possible Control by Bacteriophages. Appl. Sci. 2021, 11, 735. https:// doi.org/10.3390/app11020735

Received: 19 December 2020 Accepted: 10 January 2021 Published: 14 January 2021

Publisher's Note: MDPI stays neutral with regard to jurisdictional clai$\mathrm{ms}$ in published maps and institutional affiliations.

Copyright: $(\odot 2021$ by the authors. Licensee MDPI, Basel, Switzerland. This article is an open access article distributed under the terms and conditions of the Creative Commons Attribution (CC BY) license (https:// creativecommons.org/licenses/by/ $4.0 /)$.

\begin{abstract}
Sulfate-reducing bacteria (SRB) represent a group of prokaryotic microorganisms that are widely spread in the anoxic environment (seabed, riverbed and lakebed sediments, mud, intestinal tract of humans and animals, metal surfaces). SRB species also have an impact on processes occurring in the intestinal tract of humans and animals, including the connections between their presence and inflammatory bowel disease (IBD). Since these SRB can develop antimicrobial resistance toward the drugs, including antibiotics and antimicrobial agents, bacteriophages could represent an additional potential effective treatment. The main objectives of the review were as follows: (a) to review SRB (both from intestinal and environmental sources) regarding their role in intestinal diseases as well as their influence in environmental processes; and (b) to review, according to literature data, the influence of bacteriophages on SRB and their possible applications. Since SRB can have a significant adverse influence on industry as well as on humans and animals health, phage treatment of SRB can be seen as a possible effective method of SRB inhibition. However, there are relatively few studies concerning the influence of phages on SRB strains. Siphoviridae and Myoviridae families represent the main sulfide-producing bacteria phages. The most recent studies induced, by UV light, bacteriophages from Desulfovibrio vulgaris NCIMB 8303 and Desulfovibrio desulfuricans ATCC 13541. Notwithstanding costly and medically significant negative impacts of phages on SRB, they have been the subject of relatively few studies. The current search for alternatives to chemical biocides and antibiotics has led to the renewed interest in phages as antibacterial biocontrol and therapeutic agents, including their use against SRB. Hence, phages might represent a promising treatment against $\mathrm{SRB}$ in the future.
\end{abstract}

Keywords: bacteriophage therapy; combatting corrosion; sulfate-reducing bacteria; dissimilatory sulfate reduction; hydrogen sulfide; toxicity

\section{Introduction}

Bacteriophages (phages) have come into increasing prominence since there are viruses of bacteria [1,2]. Phages as antibacterial agents can be used to treat environments, both clinically or veterinary. The treatment can be described as phage-mediated bacterial biocontrol [3,4], phage therapy, or bacterial therapy [5,6]. The application of antibiotics to environments or the use of antibiotics normally employed as treatments of human infections for other means, such as in animal husbandry, has been discouraged $[7,8]$. Thereby, it has become important to find alternatives to antibiotics to control undesirable bacteria [9-13]. 
Sulfate-reducing bacteria (SRB) are a group of anaerobic microorganisms that can be present in the environment and gastrointestinal tract as a part of the intestinal microbiome and can be involved in inflammatory bowel diseases (IBDs), including ulcerative colitis in the human and animals [14-19]. They play an important role in this environmental sulfur cycle, especially in the dissimilatory sulfate reduction process. Sulfur belongs to group 16 of the periodic element system, and it makes up to $0.04 \%$ of the Earth's crust [20]. Though $\approx 100$-fold less abundant than oxygen, sulfur nevertheless plays an important role in biology. Most prominently, sulfur is found as a component of two of the naturally occurring amino acids. These two, methionine and cysteine, are both essential to the functioning of all living organisms and play unique roles in both molecular genetics and protein structure, serving as start codons and disulfide bridges, respectively. Sulfur is found as well as an abiotic component of environments. For example, it contributes to the formation of the minerals pyrite $\left(\mathrm{FeS}_{2}\right)$ and gypsum $\left(\mathrm{CaSO}_{4} \cdot 2 \mathrm{H}_{2} \mathrm{O}\right)$. Biogeochemically, sulfur can take on multiple forms involved in chemical and biological oxidation and reduction, since its oxidation numbers range from -2 in the fully reduced state to +6 in the fully oxidized state [21]. Thus, sulfur in different forms can readily serve as electron donors (biologically, these are sources of energetic elections) and electron receptors, thus serving in this latter case as electron sinks, including as analogous to the role of oxygen as a final electron acceptor [22].

SRB are widely distributed in anoxic environments where they utilize sulfate as a terminal electron acceptor, reducing them to sulfides [23-27]. They inhabit terrestrial and aquatic ecosystems, and they are part of the microbiota of animals and humans [28-32]. As decomposed organic substances serve as the electron donor, SRB thereby represent chemoheterotrophic, anaerobically respiring bacteria. The metabolite that results from this anaerobic respiration is known as hydrogen sulfide $\left(\mathrm{H}_{2} \mathrm{~S}\right)$, and it is chemically analogous to water as the metabolic byproduct of aerobic respiration (water $\left(\mathrm{H}_{2} \mathrm{O}\right)$ ). Unlike water, which represents hydrogen's most commonly fully oxidized state, $\mathrm{H}_{2} \mathrm{~S}$ can still be oxidized by sulfur bacteria, serving in this case as an energy-carrying electron donor. $\mathrm{H}_{2} \mathrm{~S}$ also can be released into the atmosphere as hydrogen sulfide gas [22].

$\mathrm{H}_{2} \mathrm{~S}$ production and release in the course of anaerobic respiration of SRB causes a wide range of issues. For example, SRB found in marine sediments are the cause of sulfur presence in petroleum, generating so-called "sour" crude oil vs. the preferred "sweet" crude oil. SRB-released $\mathrm{H}_{2} \mathrm{~S}$ is associated as well with the corrosion of steel components of machines used during oil extraction, transport, and processing [33]. In addition, SRB are part of the human and animal intestinal microbiome. Desulfomonas pigra, now called Desulfovibrio piger, was first isolated in 1976 as the part of the intestinal microbiome [34]. Notably, the sulfide resulting from the presence of these bacteria damages oral mucosa and intestinal cells, with SRB thereby potentially giving rise to bleeding diarrhea, weight loss, periodontitis, or even ulcerative colitis [35-42].

Whether as contaminants of oil processing infrastructure or components of the human intestine microbiome, reducing loads of SRB can be desirable. Bacterial resistance to antibiotics has become increasingly prevalent, leading to less effective outcomes of antibiotic treatments, and there is a need for the antibiotic use reduction. The studies are indicating the antibiotic resistance of Desulfovibrio desulfuricans isolated from people with colitis [43].

The aim of the review is to characterize the harmful effects of SRB on both infrastructure and humans, to provide an overview of the current state of SRB-phage research, and to explore the potential for bacteriophages to be used in the control of SRB.

\section{SRB Categorization and Characteristics}

Sulfate-reducing bacteria (SRB) include a wide range of otherwise unrelated prokaryotic organisms. They mainly belong to the Bacteria, but also are found among the Archaea. There are 220 known species divided into 60 genera [44,45]. SRB use sulfate as a terminal electron acceptor during the dissimilatory sulfate reduction process. The different organic compounds are used as an electron donor and carbon source by SRB. For example, these organic substances include acetate, ethanol, glucose, lactate, malate, and propionate, 
depending on the species, which collectively serve as electron donors and which also are oxidized to various distinct end products depending on species [22]. The resulting metabolic pathway-movement of electrons from an organic substance to sulfate ions, giving rise to $\mathrm{H}_{2} \mathrm{~S}$-is called dissimilatory sulfate reduction, meaning that the resulting reduced sulfur is not assimilated into these organisms but instead is released as a waste product. Examples of different types of sulfate-reducing prokaryotes and their families according to Brenner et al. (2005) are presented in Table 1 [44].

Table 1. Some types of sulfate-reducing bacteria (SRB) [44].

\begin{tabular}{cccccc}
\hline Species & Phylum & Order & Shape & Gram Staining & Mobility \\
\hline Desulfovibrio piger & Proteobacteria & Desulfovibrionales & rods & negative & no \\
\hline Desulfovibrio desulfuricans & Proteobacteria & Desulfovibrionales & vibrios & negative & yes \\
\hline Desulfovibrio vulgaris & Proteobacteria & Desulfovibrionales & vibrios & negative & yes \\
\hline Desulfobacter hydrogenophilus & Proteobacteria & Desulfovibrionales & oval rods & negative & yes \\
\hline Desulfobulbus propionicus & Proteobacteria & Desulfovibrionales & elliptical rods & negative & yes \\
\hline Desulfotomaculum acetoxidans & Firmicutes & Clostridiales & rods & positive & yes \\
\hline Caldivirga maquilingensis & Crenarchaeota & Thermoproteales & rods & - & yes \\
\hline
\end{tabular}

\subsection{Class Deltaproteobacteria}

SRB include microorganisms displaying different shapes, sizes, metabolic pathways, cell wall types, and more [44,46-48]. However, a dominating component of SRB taxonomy consists of the members of the Gram-negative bacteria, class Deltaproteobacteria of phylum Proteobacteria, including the SRB-containing orders Desulfovibrionales and Desulfobacterales. The division is largely based on 16S rRNA gene sequencing [44]. Members of order Desulfovibrionales are motile, anaerobic rods that are mostly mesophilic or thermophilic, and rarely psychrophilic. The order Desulfobacterales is more morphologically diverse than the order Desulfovibrionaceae, including not only rods but cocci and filamentous bacteria as well. They are mobile, thermally mesophilic, and sometimes psychrophilic. Slightly curved rods of Desulfobacterales mainly use lactate as an electron donor that is further oxidized to acetate, and they also require vitamins to grow. This order occurs in anoxygenic aquatic habitats. The Desulfobacterales family Desulfobulbaceae includes the genus Desulfobulbus. These lemonshaped rods populate water sediments (both freshwater and marine water). They use mainly propionate as an electron donor that oxidizes incompletely to acetate [44,45].

The Desulfovibrionaceae family consists of the following genus: Bilophila, Desulfobaculum, Desulfocurvibacter, Desulfocurvus, Desulfohalovibrio, Desulfolutivibrio, and Desulfovibrio. Desulfohalobiaceae, a family within the order Desulfovibrionales, embraces the genera Desulfohalobium, Desulfonatronospira, Desulfonatronovibrio, Desulfothermus, Desulfonauticus, Desulfovermiculus, and Desulfohalophilus [44,48]. The Desulfovibrionaceae family consists of mesophilic organisms that oxidize organic substances to acetate, most of which have a vibrio shape and one polar flagellar. An important representative is the genus Desulfovibrio, since this genus is the most often found in the environment (it encompasses the majority of species, and they are the most often found within the human and animal intestinal microbiota, especially among patients with developed intestinal bowel diseases) [44,49]. Desulfovibrio piger, which in contrast to $D$. desulfuricans consists of non-motile straight rods, represents the most abundant SRB in the human gastrointestinal tract [34]. This species in particular has been found to be present at significantly higher levels in patients suffering from chronic bowel inflammation [50,51]. By contrast, Desulfovibrio ferrophilus occurs in the marine environments that are oxygen free, where it forms crusts on the iron surfaces, resulting in corrosion. Both species are using iron as an electron donor [52]. Desulfopila corrodens requires an organic substrate to grow, such as acetate [53]. The family Desul- 
fohalobiaceae also includes the genus Desulfomonas, an irregular, immobile rod found in human stool $[32,54]$.

\subsection{Other SRB-Containing Taxa}

Sulfate-reducing bacteria are also found in other bacterial taxa. The genus Desulfotomaculum belongs to phylum Firmicutes, class Clostridia, order Clostridiales, and the family Peptococcaceae. These are spore-forming Gram-positive bacteria presenting morphologically as straight or curved rods. Their spores are oval, terminal, and subterminal. In terms of temperature sensitivity, both mesophilic and thermophilic species are included. For example, they occur in soil or deep sea sediments [55]. Among the SRB also is genus Thermodesulfovibrio, which belongs to the bacterial phylum Nitrospirae. These strict anaerobes have entirely been isolated from hot springs and hydrothermal vents [56]. In the domain Archaea, sulfate-reducing representatives (some authors use the term SRM-sulfate-reducing microorganisms) are found among the Crenarchaeota, which is a phylum historically associated with sulfur-based metabolisms [21].

\section{SRB Impact on Environments and Humans}

SRB are found in a wide variety of water and soil habitats where the environment is oxygenated and sulfates are available. They occur in freshwater, marine or brackish waters, in wetlands, hot springs, oil wells, and in sewers. Up to fifty percent of the mineralization of organic matter in the continental shelf is due to dissimilatory sulfate reduction. The resulting sulfite metabolite is oxidized by sulfur-oxidizing bacteria in the same environment [57]. The impact of SRB on the environment can be overseen through the fact that Desulfovibrio desulfuricans has been found to be able to methylate mercury (MeHg) [58]. The release of $\mathrm{MeHg}$ in marine environments occurs under anaerobic (or low oxygen) conditions, and the methylation of $\mathrm{Hg}$ (II) in freshwater systems is mainly done by sulfate-reducing bacteria or iron-reducing bacteria [59].

\subsection{Sewer System Negative Impacts of SRB Action}

Sewer systems are by nature nutrient-rich and are therefore home to a wide range of microorganisms, including SRB that grow either in sediment or biofilm at the bottom of the pipes. Problems are caused by their $\mathrm{H}_{2} \mathrm{~S}$ production. It diffuses from the lower layers of the biofilm up to the oxic conditions, where it is oxidized biologically (for example by bacteria of the family Thiomonas and Thiobacillus) or instead abiotically [60]. Abiotic oxidation of sulfide represents the oxidation where physico-chemical processes are included, meaning that the reduced iron and/or manganese oxidation leads to the improvement of the kinetics of sulfide oxidation with the formation of oxidized metals [60]

The resulting sulfates (based on the $\mathrm{SO}_{4}{ }^{2-}$ ion) and sulfuric acid $\left(\mathrm{H}_{2} \mathrm{SO}_{4}\right)$ react with concrete, which is a material frequently used for the construction of sewers. One of the common components of concrete is gypsum $\left(\mathrm{CaSO}_{4}\right)$, which comes into contact with sulfates corrodes to ettringite $\left(\mathrm{Ca}_{6} \mathrm{Al}_{2}\left(\mathrm{SO}_{4}\right)_{3}(\mathrm{OH})_{12} \cdot 26 \mathrm{H}_{2} \mathrm{O}\right)$ [61]. Ettringite expands and causes cracks and loss of concrete coherence. Due to the production of sulfuric acid, $\mathrm{pH}$ also decreases, resulting in biofilms formed by acidophilic microorganisms, which further increases the surface acidity. $\mathrm{H} 2 \mathrm{~S}$ and acetate produced by SRB are lowering $\mathrm{pH}$ on the metal surface. This process could lead to a higher corrosion rate [62]. Additionally, sulfane threatens the health and life of sewer workers $[63,64]$.

Constantly, new strains of SRB are found, such as Desulfovibrio vulgaris strain Hildenborough (isolated from sediment of a heavy metal impacted lake). Bacteriophages related to specific SRB are also usually revealed with new strains $[65,66]$.

Already in 1973, scientists from the University of Kansas observed phage-infecting Desulfovibrio vulgaris. Bacterial cells were stressed by both UV radiation and mitomycin C. At first glance, no lysis was observed after antibiotic addition, but the size of individual cells increased and appeared more pleomorphic. Therefore, the suspension was centrifuged several times, and then, the pellet was examined under an electron microscope. The observers 
were not sure whether they were phage, but they mention that "particle morphology is typical of phage belonging to Bradley Group A" [67]. The differences among bacteriophages of different Desulfovibrio vulgaris strains can be overviewed through the differences between D. vulgaris NCIMB 8303 and D. desulfuricans ATCC 13541. These strains showed different restriction enzyme cleavage patterns and different protein profiles [65-67].

Rapp and Wall (1987) found phage capable of gene transduction in Desulfovibrio desulfuricans. It was observed that the virus is capable of transferring rifampicin and nalidixic acid resistance between strains [68]. A lytic bacteriophage was isolated in 1988 in Japan. Scientists separated phage from muddy sediment samples collected at low tide and tested it on a laboratory strain of Desulfovibrio salexigens. Based on electron microscope observations, they reported that these viruses have a regular icosahedral head and a long non-contractile flagellum. They were morphologically similar to coliphage $\lambda$, which is a member of the family Styloviridae. The nucleic acid has been characterized as dsDNA $[69,70]$.

In the early 1990s, further attempts were made in Kansas to induce lysogenic phages in Desulfovibrio vulgaris, which is a strain of Hildenborough and Desulfovibrio desulfuricans. This was successful, based on restriction analysis and DNA hybridization, and it was found that the viruses of the two organisms did not share DNA homology and thus probably did not share a common ancestor. Further research has focused on comparing strains of $D$. vulgaris Hildeborough, which has been described in earlier studies, and strain DePue, which was isolated from sediment of a heavy metal contaminated lake. The sequence similarity of the 16S rRNA gene was over 99\%; however, the DePue strain had a significantly reduced genome compared to the previous one. Its genome lacked most of the genes that were annotated as phages or phage-related in strain Hildeborough. Strain DePue were also susceptible to prophages induced in the Hildeborough strain. This correlates with the finding that DNA does not contain prophages related to those induced. The analysis indicated that prophages have a strong influence on the overall genome of individuals of this species; perhaps, they may also provide a selective advantage in certain environments [71,72].

Research into SRB-targeting bacteriophages may have practical implications in suppressing and controlling their population. The cell can prevent the virus from being infected in the first step of the phage process by preventing the phage adsorption to the cell. The structure of the receptor to which the bacteriophage binds may be mutated, or the receptor may be masked by other proteins, but the phage may adapt to this change [73]. Bacteria can secrete into the extracellular space a polysaccharide matrix that forms a physical barrier between the bacteriophage and the microbe. However, some phages are able to enzymatically cleave this barrier or use the matrix itself as a recognition site [74]. Sometimes, bacteria produce competitive receptor inhibitors. These substances naturally occur in the vicinity of bacteria and can specifically bind to receptors that then are unusable for phages [75]. Mostly, bacteria and archaea contain a restriction modification system that prevents the cell from foreign DNA. Restriction enzymes in the cytoplasm recognize and degrade unmethylated DNA. In some cases, nucleic acid is methylated by methylase, causing a loss of sensitivity of bacteriophage DNA to restriction enzymes [76,77].

\subsection{The Relationship between Iron Corrosion and SRB Presence}

Another material that corrodes as a result of SRB action is metallic iron $\left(\mathrm{Fe}^{0}\right)$, including as a component of steel. Iron corrosion in the presence of SRB is accelerated [53]. Corrosive SRB prefer the direct consumption of electrons derived from iron than from $\mathrm{H}_{2}$ [78,79]. According to this theory, the iron in contact with water loses positive ions and thereby is polarized. In an anoxic environment, the released electrons then combine with protons dissociated from water to form $\mathrm{H}_{2}$. This remains in equilibrium on the metal surface. However, this equilibrium is perturbed by SRB utilizing $\mathrm{H}_{2}$, resulting in a driving of the reaction instead toward further metal oxidation. Other possible corrosion mechanisms have been proposed. More than a decade ago, a study suggested that bacterial strains that 
use iron as a direct electron donor without a hydrogen intermediate can also be involved in corrosion [80,81]. These strains include species later called Desulfovibrio ferrophilus and Desulfopila corrodens. Electrons are also gained through the formed crust of iron sulfate (FeS) and ferrous carbonate $\left(\mathrm{FeCO}_{3}\right)$, and they form a conductive mixture. Since SRB damage worldwide pipelines and result in hundreds of millions of dollars lost annually, bacteriophage treatment of SRB can reduce these costs significantly. It is well known that corrosion control is a big economic issue [82].

\subsection{Oil and Gas Industry}

SRB can be found both below and above the ground, and their presence raises several problems in terms of oil extraction and processing. For example, their presence within oil extraction and processing equipment raises several problems due to the aforementioned corrosion of metals. This results in damage to numerous equipment components, thereby increasing costs. In addition, metabolites such as $\mathrm{H}_{2} \mathrm{~S}$ are dangerous for workers associated with this sector. By burning oil, the sulfur it contains-another consequence of SRB action, which in this case occurs predominantly below the ground-also gets into the atmosphere, resulting in the acidification of rain by the oxidation of $\mathrm{H}_{2} \mathrm{~S}$ to sulfuric acid [78].

As noted in the Introduction, in the mining industry, oil is classified according to its sulfur content into "sweet" (sweet crudes), common, and "sour" (sour crudes). Sweet crudes, so named owing literally to its sweet taste, can contain by convention a maximum of $0.5 \%$ sulfur, and this is both the highest quality and the most valued of crude oils. By contrast, ordinary crude oil contains $0.5-1.5 \%$ sulfur, and crude oils containing even higher percentages of sulfur are considered to be sour. Sulfur content not only can lead to the formation of $\mathrm{H}_{2} \mathrm{~S}$, it also has to be removed from oil prior to burning, and doing so is costly. Oil "acidification" is often associated with the tertiary phase of oil extraction, that is, when oil from wells no longer reaches the surface without additional pressurization. That additional pressurization is accomplished via what is known as the irrigation method, and this involves the pumping of sea water into wells to increase volumes and therefore pressure levels. A mixture of water, oil, and natural gas is formed by this process, which is subsequently fractionated on the surface, and the released water again forced into the deposit. In this way, the extraction of residue oil is achieved, which would not be otherwise achievable due to pressure loss. However, by introducing sea water, a certain amount of sulfate and SRB enters into the well. Then, this can significantly increase the content of sulfide due to SRB metabolic activity [83].

\subsection{Intestinal SRB and Their Association with Diseases}

SRB are a natural part of the colonic microbiota of animals and humans [84-89]. They are involved in the utilization of $\mathrm{H}_{2}$ produced in the intestine as a result of the fermentation of sugars. Intestinal SRB use organic compounds as an electron donor [90-93]. In this respect, they have a competitive relationship with other $\mathrm{H}_{2}$ metabolizing organisms for the acquisition of electrons, namely methanogenic archaea (for example, Methanobrevibacter smithii). The availability of sulfate, which also is a component of food, plays important roles in intestinal SRB growth as well. Endogenous sources of sulfate, such as mucin or chondroitin sulfate, are also present in the intestine but must be treated by the lytic action of other bacteria such as clostridia [94].

The defining metabolic by-product associated with SRB is, of course, $\mathrm{H}_{2} \mathrm{~S}$ [95-97]. At higher concentrations, $\mathrm{H}_{2} \mathrm{~S}$ has carcinogenic and toxic effects on intestinal cells. It also blocks the binding of oxygen to cytochrome c and inhibits its functionality [98,99]. By binding to heme a3 cytochrome, the binding of oxygen is disabled and thereby causes oxidative phosphorylation, interrupting the formation of ATP [99]. $\mathrm{H}_{2} \mathrm{~S}$ also acts mutagenically on DNA and, by its ability to reduce disulfide bridges, it can also disrupt protein structures [99-103]. SRB are often associated with idiopathic intestinal inflammation, such as ulcerative colitis. In this disease, an increased amount of SRB [101] and an increased concentration of $\mathrm{H}_{2} \mathrm{~S}$ have been found as compared to healthy patients [102,103]. However, 
the results are not showing fully unambiguous correlations. On the other side, the high prevalence of intestinal bowel disease among inhabitants, especially in Western countries, emphasizes the importance of studies dealing with SRB occurrences as well as their intestinal environments [84-86].

Bacteria are constantly developing new anti-phage defenses, due to which phages go through constant evolution, too. Anti-phage systems are mainly based on protein components that mediate defense. Protein involvement in anti-phage bacterial systems is the most understood bacterial defense against phages. Chemical anti-phage defense systems are widely developed in Streptomyces [104]. Another common bacterial anti-phage system is the microbial cell surface modification that does not allow phage attachment. The CRISPR-Cas defense system represents a more advanced anti-phage bacterial strategy, since it is based on phage sequences, capturing and using it to prime a response that inhibits phage growth. The addition of methyl groups to DNA and degrading other DNA without methyl groups is another bacterial tactic against phages. Certainly, there are also other more specific bacterial single cell developed anti-phage systems and strategies [105].

Epithelial cells secrete mucin, which creates a chemical and mechanical barrier against bacteria, while also lubricating the intestines and hydrating them. These glycoproteins contain the rigid MUC2 protein. $\mathrm{H}_{2} \mathrm{~S}$ degrades the structural integrity of mucous layers by reducing the disulfide bridges that bind mucin units. This causes a decrease in polymer binding, and bacteria can therefore more easily reach the epithelial cells where they can induce an immune response or directly damage the cells [103].

\subsection{Research in the Field of SRB Bacteriophages}

All of the above negative effects associated with $\mathrm{H}_{2} \mathrm{~S}$ production lead to considerations of how to suppress SRB metabolic activities [106-113]. Alternatively, it may be possible to combat the nuisance of SRB through the use of bacteriophages $[10,65,66,70]$. Superinfection (SI) exclusion systems are complexes of proteins in the membrane that prevent viral DNA from penetrating to the cell. These proteins are often encoded by prophage genes and are intended to counteract the body's superinfection, preventing the bacterium from being infected with the same or a similar virus several times, thereby reducing the viability of an already infected bacterium [76].

Viruses in total are the most abundant group of "organisms" in the world with the amount measured microscopically in aquatic systems present, e.g., at $10^{7}$ per milliliter [114], which is somewhat higher in sediments [115]. The total population is estimated to be $10^{31}$ entities [116]. Given the great abundance of bacteria, most of these viruses are thought to be bacteriophages.

Bacteriophages can be divided in two main groups [117]: tailed and tailless. They can also be distinguished into a number of different infection types [118]: lytic phage, chronic phage, and latent phage. Lysogenic cycles are associated with what are known as temperate phages [67], while phages that are unable to display lysogenic cycles, but instead only lytic cycles, can be described as strictly or obligately lytic. Temperate phages are of interest especially due to their ability to modify bacterial hosts both genetically and phenotypically [68,70-72], whereas strictly lytic phages ideally are what is employed for phage-mediated biocontrol and phage therapy. It is thought that most phages are lytic (whether strictly lytic or instead temperate); in nature, both types of phages serve as natural antagonists of bacteria.

Since $\mathrm{H}_{2} \mathrm{~S}$ is produced by SRB and it represents the harmful compound in the environment, phages represent an important factor for the elimination of SRB genera. The main sulfide-producing bacteria (SPB) phages belong to families of Siphoviridae and Myoviridae. Phage activities toward SPB are the most effective at $30^{\circ} \mathrm{C}$ and less effective at $20^{\circ} \mathrm{C}$ [119]. The lysogenic bacteriophage belonging to Styloviridae (Siphoviridae is a new name according to the ICTV (International Committee on Taxonomy of Viruses)) lyses salt-requiring SRB, Desulfovibrio salexigens [70]. 
Bacteriophages are responsible for $60-70 \%$ of all problems occurring during the fermentation of different food commodities (bacteriophages can delay and inhibit fermentation processes) [120]. Spontaneous fermentation is changed with starter cultures due to more controlled processes. Lactobacillus plantarum strains (mainly used in vegetable fermentation) were found to be $25 \%$ sensitive to bacteriophages [121]. However, there is a difference in phage infection rate. Phage infection rate is considered fast if bacterial lysis occurs within $2 \mathrm{~h}$ after infection [122]. Bacteriophages found during fermentation processes are usually eliminated after $30 \mathrm{~min}$ treatment at $80^{\circ} \mathrm{C}$ and $90^{\circ} \mathrm{C}$ (they can survive the time and temperature used in standard food pasteurization). It means that they are resistant to the environments during food fermentation, especially because it was found that bacteriophages grow under broad $\mathrm{pH}$ values [123]. When phages titer increases over $10^{6} \mathrm{PFU} / \mathrm{mL}$, the fermentation is usually inhibited [124].

As outlined in previous sections, a number of taxa include members that are sulfate reducing, and these bacteria can be found within a variety of contexts, where in some of those contexts, they can be problematic, e.g., such as due to negative impacts on infrastructure (e.g., pipes) or health (e.g., the human intestine). As generally, it is thought that all or at least most bacteria types possess at least one associated phage, it should be assumed that most or all SRB also have associated phages. A variety of methods exist toward phage discovery, the most traditional of which is simply isolation as plaques against a given bacterial host [118]. Generally, this isolation is most conveniently and therefore most typically takes place when working with bacteria that are able to readily form lawns on agar surfaces. For bacteria requiring anaerobic environments for growth, phages are still readily isolated and propagated, e.g., as within anaerobic chambers. Generally, many more phages have been isolated, and their role in bacterial infection has been studied. Here, we provide a comprehensive overview of SRB-infecting phages isolated from specific SRB hosts.

Previous studies induced bacteriophages from cultures of Desulfovibrio vulgaris NCIMB 8303 and Desulfovibrio desulfuricans ATCC 13541 by UV light. The UV effect during 9 to 10 $\mathrm{h}$ resulted in the phage maximum yield. Nucleic acids of phages from both cultures $(D$. vulgaris NCIMB 8303 and D. desulfuricans ATCC 13541) were cut by restriction endonucleases (specific for double-stranded DNA). DNAs of phages from these two cultures showed different restriction enzyme cleavage patterns. The homology was not noticed between a $25 \mathrm{~kb}$ phage DNA of D. vulgaris and D. desulfuricans. The protein profiles of isolated phages from these two cultures were also analyzed, and it was found that the $D$. vulgaris phage contained two major bands (Mr values of 37,000 and 56,000) and the D. desulfuricans phage contained only one major band (Mr 38,000) [125].

Bacteriophage isolated from $D$. vulgaris was defined through establishing a preliminary endonuclease restriction map. The mapping succeeded in linking four BamHI fragments into two DNA segments, though not linking was detected between the two segments. The obtained results from the authors lead to the conclusion that two phages were induced from $D$. vulgaris culture. The results in the study were supported by the size approximation of restriction enzyme fragments, electron micrographs, and density gradients [126].

\section{Possibility of Application of SRB Bacteriophages in Practice}

Using bacteriophages as an antibacterial method has some advantages. Due to specific absorption to only certain receptors on the cell surface, they attack only the genus, species, and sometimes only one particular bacterial strain. Therefore, unlike antibiotics, they do not destroy other microorganisms in the body that may be useful to organisms. At the same time, the virus consists only of proteins and nucleic acids, which thus does not cause side effects after degradation [127].

The development of new biotechnology and pharmaceutical products is possible with the use of bacteriophage particles. Bacteriophage therapy as the antimicrobial treatment, especially against resistant bacterial infections had been known before, recently has been rediscovered again, since phage-based vaccination represents one of the most promising 
preventive strategies. That is the reason and necessity for the constant discussions and research studies concerning the biological nature of phages, including phage therapy, drug delivery, tissue engineering, food biopreservation and safety, biocontrol of plant pathogens, vaccines and vaccine carriers, biofilm and bacterial growth control, surface disinfection, corrosion control, and other important fields of phages impact [128].

On the other hand, recent achievements in nanotechnology are improving the possibilities for phage manipulation. The essentials for the new science field, such as bionanomedicine, are of crucial importance to control the physical, chemical, and biological properties of materials. Phages, similar to viruses, represent a promising nanomaterial that can be manipulated with great precision, since phage particles are formed according to the genetic information (in protein shells), and their sizes and shapes are precisely defined. Genetic engineering and chemical modification allow the control of the composition and surface properties of phage particles. These modifications can lead to the improvement and better quality of human health [129].

It is certain that new phage therapies will have to solve problems, such as potential phage toxin elimination, inadequate phage purification, and the limited knowledge of relations between humans and phages. Control clinical studies are necessary for the application of new phage therapies; these studies are always costly and time consuming, but they are regulated by states' laws. The researches and systematic reviews about phages represent steps toward better understanding of phages interactions with host cells [130].

Another disadvantage of phage therapies is a lack of systematic studies about phage pharmacokinetic data. According to animal studies, phages end most often in the liver, although there is some trapping in the spleen [131]. It is possible to choose some phage strains that are capable of remaining in the circulation and act constantly against bacterial infections [132,133], the same as strains with a reduced immunogenicity (the reduction of phage adverse reactions). So-called "platform" phages and "dual" specificity phages would be necessary to be developed or engineered, free of antibiotic-resistant genes and toxins $[130,134]$.

Phages also act locally at the site of host bacteria. The phage particle produces over a hundred new virions in a single cycle, these viruses again attack neighboring bacteria, and the number of phages destroying bacteria increases exponentially. The use of phages with antibiotics also reduces the chances of creating bacterial resistance to both [135]. However, phage therapy has its drawbacks. One of its greatest weaknesses is its high specificity. In order to initiate therapy, it is necessary to know the pathogen that caused the infection. In acute cases, it is excluded. In these cases, the application of a phage cocktail or polyvalent phage may be considered, but antibiotic formulations have superiority in the rate of action [136].

Certain criteria for a suitable phage preparation must be followed to avoid unwanted side effects of therapy. It is necessary to identify and classify the phage according to the ICTV system, using mainly DNA sequences or electron microscopy. Therapeutic phages should be able to reproduce by lytic life cycle. The effect of lytic phages is faster, because they always destroy cells directly, and also, there is less chance of transduction. Propagates that become part of the genome may inaccurately cleave to lytic cycle and transfer bacterial genes (such as antibiotic resistance) to another individual [137]. Despite the praised ability of phages to attack and destroy unwanted bacteria, this method has its negative side, too. These viruses develop concurrently with their hosts as part of evolutionary dynamics. While the chances of developing bacterial resistance to antibiotics are higher than those of bacteriophages, this chance still exists, since bacteria have different ways of dealing with viruses. An important industry where phage phenomena are often declining against SRB is the oil industry. Against biocorrosion, which causes enormous damage to the infrastructure of the oil processing industry, chemical biocidal agents are often used, which are inserted into oil pipelines to destroy harmful microorganisms. However, these preparations have low efficacy against bacteria in biofilms, where the extracellular matrix produced by the cells often protects them from damage [138]. 
However, bacteriophages may have the ability to break down the polysaccharide complexes and, consequently, to lyse the cells. The biocorrosion phage control procedure was patented in America in 2009 [139]. First, corrosion agents in pipes and other equipment are to be identified and isolated. Subsequently, mixtures of lytic bacteriophages will be formed, which will inhibit the growth of (not only) SRB. Existing isolates as well as those newly obtained from industrial and environmental samples can be used. As an ideal environment, the text mentions water sediments, taking into account the physicochemical properties of sediments. The exact procedure should be based on the known characteristics of the species identified at the corrosion site. Thereafter, the effectiveness of the phage isolate against the sample originating from the damaged sites is tested. Then, the bacteriophage lysate will be optimized, for example by mutagenesis and targeted selection or genetic engineering. The targeted creation of new phages is also not excluded. The patent proposes using "pigging" to transport the product to the site. This procedure uses a cylindrical device, known as a "pig", to inspect and clean the tubes without stopping the flow of products therein. In this case, the "pig" is intended to release virus-containing fluid or gel in the tubes. For example, phages can be injected into the surrounding sediment to treat the outer surface of the tubes [140].

It also offers a similar approach to solving the problem of "acid" oil. For the identified SRB producing $\mathrm{H}_{2} \mathrm{~S}$, a first mix of phages against this population should be created. At the same time, a second mixture is produced, designed, and adapted to the bacteria in the water, which will flood the site to maintain the pressure and extraction efficiency. In doing so, it seeks to combat two originally separate populations of bacteria that degrade oil [140]. Two years later, the scientists have isolated two bacteriophages from marine black sediment, where Desulfovibrio and Haloanaerobium formed a synergistic culture [141,142].

The authors of this technological procedure based their method on the phases with a lytic cycle, to which it is suggested to add the use of biocides to achieve the greatest effect [138]. Another option is to use prophages. In many Desulfovibrio species, several prophage elements are present in the genome. In these viruses, the transition to the virulent phase can be induced by stressing the bacterial cells with, for example, UV radiation or antibiotics. According to prophage linkage within strains and same species, it seems that one virus may be able to attack multiple strains [143]. However, overall, methods of using bacteriophages against SRB compared to other groups are only at the beginning of development. More data are needed both on the exact nature and interactions of bacteriophages in biofilm, which causes bio-corrosion damage, and on the other hand, little information on the specificities of bacteriophages targeting a diverse group of organisms such as SRB is known.

\section{Conclusions}

Bacteriophages are a diverse group of viruses that infect prokaryotic organisms. The species specificity of the phages is derived from the presence of a particular receptor on the surface of the bacterial cell. The genetic information of most important bacteriophages is expressed in DNA. Upon penetration of the DNA of the virus into the cell, the virulent phages enter the lytic cycle and are tempered; they may be lysogenic or even lytic. The research of bacteriophages has been coming to the forefront of the scientific community for the past decade; phage model organisms such as from Escherichia coli have been extensively studied. However, the group of SRB has become a subject of widespread interest only in recent years. Therefore, the study of their bacteriophages and the related amount of information have been published only to a limited extent.

SRB are a group of anaerobic organisms characterized by a metabolism using dissimilatory sulfate reduction. This bacterial community reduces sulfate associated with the oxidation of organic substrates or $\mathrm{H}_{2}$. SRB inhabit a variety of anoxic environments, which are found in marine and freshwater sediments, in the soil, and in the intestines of humans and animals. The excreted metabolite, $\mathrm{H}_{2} \mathrm{~S}$, is toxic, and its production by SRB presents numerous problems to humans. Phages specialize only in a very narrow host spectrum 
and are therefore gentler on the body than antibiotics. On the other hand, it is necessary to know the causative agent of the infection for use in clinical practice, which may take too long. Bacteriophages are beginning to be more researched for use in medicine and industries to eliminate unwanted microorganisms. In some sectors, this is already being used, for example in poultry farming, but specifically, phage research against SRB is still in its infancy, and the application is largely theoretical. It is necessary to further and more deeply study the specifics of this issue. However, the renewed interest of the scientific community can mean a rapid shift toward practical application.

Author Contributions: Conceptualization, I.K. and D.D.; methodology, I.K.; validation, D.D.; formal analysis, I.K. and D.D.; investigation, M.V.; data curation, I.K. and M.V.; writing-original draft preparation, D.D., M.V., I.K.; writing-review and editing, I.K. and S.K.-M.R.R.; visualization, I.K.; supervision, M.V. and I.K.; project administration, M.V.; funding acquisition, M.V. and S.K.-M.R.R. All authors have read and agreed to the published version of the manuscript.

Funding: This research was supported by Grant Agency of the Masaryk University (MUNI/A/0947/2019).

Institutional Review Board Statement: Not applicable.

Informed Consent Statement: Not applicable.

Data Availability Statement: Not applicable.

Acknowledgments: Open access funding by the University of Vienna.

Conflicts of Interest: The authors declare no conflict of interest.

\section{References}

1. Kutter, E.; Sulakvelidze, A. (Eds.) Bacteriophages: Biology and Applications; CRC Press: Boca Raton, FL, USA, 2004.

2. Sulakvelidze, A.; Kutter, E. Bacteriophage Therapy in Humans. Bacteriophages Biol. Appl. 2004, $14,381$.

3. Harper, D.R.; Parracho, H.M.; Walker, J.; Sharp, R.; Hughes, G.; Werthén, M.; Morales, S. Bacteriophages and biofilms. Antibiotics 2014, 3, 270-284. [CrossRef]

4. Harper, D.R.; Anderson, J.; Enright, M.C. Phage therapy: Delivering on the promise. Ther. Deliv. 2011, 2, 935-947. [CrossRef] [PubMed]

5. Kutter, E.; De Vos, D.; Gvasalia, G.; Alavidze, Z.; Gogokhia, L.; Kuhl, S.; Abedon, S.T. Phage therapy in clinical practice: Treatment of human infections. Curr. Pharm. Biotechnol. 2010, 11, 69-86. [CrossRef]

6. Abedon, S.T.; Kuhl, S.J.; Blasdel, B.G.; Kutter, E.M. Phage treatment of human infections. Bacteriophage 2011, 1, 66-85. [CrossRef] [PubMed]

7. Pieterse, R.; Todorov, S.D. Bacteriocins: Exploring alternatives to antibiotics in mastitis treatment. Braz. J. Microbiol. 2010, 41, 542-562. [CrossRef]

8. Feres, M. Antibiotics in the treatment of periodontal diseases: Microbiological basis and clinical applications. Ann. R. Australas. Coll. Dent. Surg. 2008, 19, 37.

9. Gonec, T.; Kos, J.; Nevin, E.; Govender, R.; Pesko, M.; Tengler, J.; Tengler, J.; Kushkevych, I.; O’Mahony, J. Preparation and biological properties of ring-substituted naphthalene-1-carboxanilides. Molecules 2014, 19, 10386-10409. [CrossRef]

10. Kushkevych, I.; Vítězová, M.; Kos, J.; Kollár, P.; Jampilek, J. Effect of selected 8-hydroxyquinoline-2-carboxanilides on viability and sulfate metabolism of Desulfovibrio piger. J. Appl. Biomed. 2018, 16, 241-246. [CrossRef]

11. Kushkevych, I.; Kollar, P.; Suchy, P.; Parak, T.; Pauk, K.; Imramovsky, A. Activity of selected salicylamides against intestinal sulfate-reducing bacteria. Neuro Endocrinol. Lett. 2015, 36, 106-113.

12. Kushkevych, I.; Kollar, P.; Ferreira, A.L.; Palma, D.; Duarte, A.; Lopes, M.M.; Bartos, M.; Pauk, K.; Imramovsky, A.; Jampilek, J. Antimicrobial effect of salicylamide derivatives against intestinal sulfate-reducing bacteria. J. Appl. Biomed. 2016, 14, 125-130. [CrossRef]

13. Kushkevych, I.; Kos, J.; Kollar, P.; Kralova, K.; Jampilek, J. Activity of ring-substituted 8-hydroxyquinoline-2-carboxanilides against intestinal sulfate-reducing bacteria Desulfovibrio piger. Med. Chem. Res. 2018, 27, 278-284. [CrossRef]

14. Kushkevych, I.; Dordević, D.; Vítězová, M. Toxicity of hydrogen sulfide toward sulfate-reducing bacteria Desulfovibrio piger Vib-7. Arch. Microbiol. 2019, 201, 389-397. [CrossRef]

15. Kushkevych, I.; Dordević, D.; Kollar, P.; Vítězová, M.; Drago, L. Hydrogen Sulfide as a Toxic Product in the Small-Large Intestine Axis and its Role in IBD Development. J. Clin. Med. 2019, 8, 1054. [CrossRef]

16. Kushkevych, I.; Kotrsová, V.; Dordević, D.; Buňková, L.; Vítězová, M.; Amedei, A. Hydrogen Sulfide Effects on the Survival of Lactobacilli with Emphasis on the Development of Inflammatory Bowel Diseases. Biomolecules 2019, 9, 752. [CrossRef]

17. Kushkevych, I.V. Kinetic Properties of Pyruvate Ferredoxin Oxidoreductase of Intestinal Sulfate-Reducing Bacteria Desulfovibrio piger Vib-7 and Desulfomicrobium sp. Rod-9. Pol. J. Microbiol. 2015, 64, 107-114. [CrossRef] 
18. Kushkevych, I.; Fafula, R.; Parak, T.; Bartoš, M. Activity of $\mathrm{Na}^{+} / \mathrm{K}^{+}$-activated $\mathrm{Mg}^{2+}$-dependent ATP hydrolase in the cell-free extracts of the sulfate-reducing bacteria Desulfovibrio piger Vib-7 and Desulfomicrobium sp. Rod-9. Acta Vet. Brno 2015, 84, 3-12. [CrossRef]

19. Kushkevych, I.V. Activity and kinetic properties of phosphotransacetylase from intestinal sulfate-reducing bacteria. Acta Biochem. Pol. 2015, 62, 1037-1108. [CrossRef]

20. Boyd, C.E. Water Quality: An Introduction; Springer: New York, NY, USA, 2019.

21. Koschorreck, M. Microbial sulphate reduction at a low pH. FEMS Microbiol. Ecol. 2008, 64, 329-342. [CrossRef] [PubMed]

22. Muyzer, G.; Stams, A.J. The ecology and biotechnology of sulphate-reducing bacteria. Nat. Rev. Microbiol. 2008, 6, 441-454. [CrossRef]

23. Kushkevych, I.; Kováč, J.; Vítězová, M.; Vítěz, T.; Bartoš, M. The diversity of sulfate-reducing bacteria in the seven bioreactors. Arch. Microbiol. 2018, 200, 945-950. [CrossRef] [PubMed]

24. Abdulina, D.; Kováč, J.; Iutynska, G.; Kushkevych, I. ATP sulfurylase activity of sulfate-reducing bacteria from various ecotopes. 3Biotech 2020, 10, 55. [CrossRef]

25. Černý, M.; Vítězová, M.; Vítěz, T.; Bartoš, M.; Kushkevych, I. Variation in the distribution of hydrogen producers from the clostridiales order in biogas reactors depending on different input substrates. Energies 2018, 11, 3270. [CrossRef]

26. Kushkevych, I.; Vítězová, M.; Vítěz, T.; Bartoš, M. Production of biogas: Relationship between methanogenic and sulfate-reducing microorganisms. Open Life Sci. 2017, 12, 82-91. [CrossRef]

27. Kushkevych, I.; Vítězová, M.; Vítěz, T.; Kováč, J.; Kaucká, P.; Jesionek, W.; Bartoš, M.; Barton, L. A new combination of substrates: Biogas production and diversity of the methanogenic microorganisms. Open Life Sci. 2018, 13, 119-128. [CrossRef]

28. van der Hoeven, J.; van der Kieboom, C.; Schaeken, M. Sulfate-Reducing Bacteria in the Periodontal Pocket. Oral. Microbiol. Immun. 1995, 10, 288-290. [CrossRef]

29. Langendijk, P.S.; Kulik, E.M.; Sandmeier, H.; Meyer, J.; van der Hoeven, J.S. Isolation of Desulfomicrobium orale sp. Nov. and Desulfovibrio Strain NY682, Oral Sulfate-Reducing Bacteria Involved in Human Periodontal Disease. Int. J. Syst. Evol. Microbiol. 2001, 51, 1035-1044. [CrossRef]

30. Goldstein, E.J.C.; Citron, D.M.; Peraino, V.A.; Cross, S.A. Desulfovibrio Desulfuricans Bacteremia and Review of Human Desulfovibrio Infections. J. Clin. Microbiol. 2003, 41, 2752-2754. [CrossRef]

31. Kushkevych, I.; Coufalová, M.; Vítězová, M.; Rittmann, S.K.M. Sulfate-Reducing Bacteria of the Oral Cavity and Their Relation with Periodontitis-Recent Advances. J. Clin. Med. 2020, 9, 2347. [CrossRef]

32. Loubinoux, J. Reclassification of the Only Species of the Genus Desulfomonas, Desulfomonas pigra, as Desulfovibrio piger. Comb. Nov. Int. J. Syst. Evol. Microbiol. 2002, 52, 1305-1308.

33. Tang, K.; An, S.; Nemati, M. Evaluation of autotrophic and heterotrophic processes in biofilm reactors used for removal of sulphide, nitrate and COD. Bioresour. Technol. 2010, 101, 8109-8118. [CrossRef] [PubMed]

34. Moore, W.E.; Johnson, J.L.; Holdeman, L.V. Emendation of Bacteroidaceae and Butyrivibrio and descriptions of Desulfomonas gen. nov. and ten new species of the genera Desulfomonas, Butyrivibrio, Eubacterium, Clostridium and Ruminococcus. Int. J. Syst. Bact. 1976, 26, 238-252. [CrossRef]

35. Dordević, D.; Jančíková, S.; Vítězová, M.; Kushkevych, I. Hydrogen sulfide toxicity in the gut environment: Meta-analysis of sulfate-reducing and lactic acid bacteria in inflammatory processes. J. Adv. Res. 2020, 27, 55-69. [CrossRef] [PubMed]

36. Kushkevych, I.; Dordević, D.; Vítězová, M. Possible synergy effect of hydrogen sulfide and acetate produced by sulfate-reducing bacteria on inflammatory bowel disease development. J. Adv. Res. 2020, 27, 71-78. [CrossRef]

37. Loubinoux, J.; Bisson-Boutelliez, C.; Miller, N.; Le Faou, A.E. Isolation of the Provisionally Named Desulfovibrio Fairfieldensis from Human Periodontal Pockets. Oral Microbiol. Immunol. 2002, 17, 321-323. [CrossRef]

38. Kováč, J.; Vítězová, M.; Kushkevych, I. Metabolic activity of sulfate-reducing bacteria from rodents with colitis. Open Med. 2018, 13, 344-349. [CrossRef]

39. Kushkevych, I.; Vítězová, M.; Fedrová, P.; Vochyanová, Z.; Paráková, L.; Hošek, J. Kinetic properties of growth of intestinal sulphate-reducing bacteria isolated from healthy mice and mice with ulcerative colitis. Acta Vet. Brno 2017, 86, 405-411. [CrossRef]

40. Kováč, J.; Kushkevych, I. New modification of cultivation medium for isolation and growth of intestinal sulfate-reducing bacteria. In Proceedings of the International PhD Students Conference Mendel Net, Brno, Czech Republic, 6-7 November 2019 ; pp. $702-707$.

41. Langendijk, P.S.; Hagemann, J.; van der Hoeven, J.S. Sulfate-Reducing Bacteria in Periodontal Pockets and in Healthy Oral Sites. J. Clin. Periodontol. 1999, 26, 596-599. [CrossRef]

42. Willis, C.L.; Gibson, R.G.; Allison, C.; Macfarlane, S.; Holt, J.S. Growth, Incidence and Activities of Dissimilatory Sulfate-Reducing Bacteria in the Human Oral Cavity. FEMS Microbiol. Lett. 1995, 129, 267-271. [CrossRef]

43. Fox, J.G.; Dewhirst, F.E.; Fraser, G.J.; Paster, B.J.; Shames, B.; Murphy, J.C. Intracellular Campylobacter-like organism from ferrets and hamsters with proliferative bowel disease is a Desulfovibrio sp. J. Clin. Microbiol. 1994, 32, 1229-1237. [CrossRef]

44. Brenner, D.J.; Krieg, N.R.; Staley, J.T.; Garrity, G.M. Volume Two: The Proteobacteria, Part C: The Alpha-, Beta-, Delta-, and Epsilonproteobacteria. In Bergey's Manual of Systematic Bacteriology, 2nd ed.; Springer: Boston, MA, USA, $2005 ;$ p. 1388.

45. Rosenberg, E.; Delong, E.F.; Lory, S.; Stackebrandt, E.; Thompson, F. The Prokaryotes. Deltaproteobacteria and Epsilonproteobacteria, 4th ed.; Springer: Berlin/Heidelberg, Germany, 2014.

46. Castro, H.F.; Williams, N.H.; Ogram, A. Phylogeny of Sulfate-Reducing Bacteria. FEMS Microbiol. Ecol. 2000, 31, 1-9. [CrossRef]

47. Postgate, J.R. The Sulphate-Reducing Bacteria, 2nd ed.; Cambridge University Press: Cambridge, UK; New York, NY, USA, 1984. 
48. Barton, L.L.; Hamilton, W.A. Sulphate-Reducing Bacteria: Environmental and Engineered Systems; Cambridge University Press: Cambridge, UK, 2010; p. 553.

49. Kushkevych, I.; Cejnar, J.; Treml, J.; Dordević, D.; Kollar, P.; Vítězová, M. Recent Advances in Metabolic Pathways of Sulfate Reduction in Intestinal Bacteria. Cells 2020, 9, 698. [CrossRef]

50. Iglesias-Rey, M.; Barreiro-de Acosta, M.; Caamaño-Isorna, F.; Vázquez-Rodríguez, I.; González, A.L.; Lindkvist, B.; DomínguezMuñoz, E. How do psychological variables influence coping strategies in inflammatory bowel disease? J. Crohn Colitis 2013, 7 , e219-e226. [CrossRef] [PubMed]

51. Loubinoux, J.; Mory, F.; Pereira, I.A.; Le Faou, A.E. Bacteremia Caused by a Strain of Desulfovibrio Related to the Provisionally Named Desulfovibrio Fairfieldensis. J. Clin. Microbiol. 2000, 38, 931-934. [CrossRef] [PubMed]

52. Sharma, M.; Liu, H.; Chen, S.; Cheng, F.; Voordouw, G.; Gieg, L. Effect of selected biocides on microbiologically influenced corrosion caused by Desulfovibrio ferrophilus IS5. Sci. Rep. 2018, 8, 16620. [CrossRef] [PubMed]

53. Enning, D.; Venzlaff, H.; Garrelfs, J.; Dinh, H.T.; Meyer, V.; Mayrhofer, K.; Widdel, F. Marine sulfate-reducing bacteria cause serious corrosion of iron under electroconductive biogenic mineral crust. Environ. Microbiol. 2012, 14, 1772-1787. [CrossRef]

54. Hillman, B. Role of Gut Bacteria in Human Toxicology and Pharmacology; CRC Press: Boca Raton, FL, USA, 2004.

55. Aullo, T.; Ranchou-Peyruse, A.; Ollivier, B.; Magot, M. Desulfotomaculum spp. and related gram-positive sulfate-reducing bacteria in deep subsurface environments. Front. Microbiol. 2013, 4, 362. [CrossRef] [PubMed]

56. Frank, Y.A.; Kadnikov, V.V.; Lukina, A.P.; Banks, D.; Beletsky, A.V.; Mardanov, A.V.; Ravin, N.V. Characterization and genome analysis of the first facultatively alkaliphilic Thermodesulfovibrio isolated from the deep terrestrial subsurface. Front. Microbiol. 2016, 7, 2000. [CrossRef]

57. Zhang, Y.; Wang, X.; Zhen, Y.; Mi, T.; He, H.; Yu, Z. Microbial diversity and community structure of sulfate-reducing and sulfur-oxidizing bacteria in sediment cores from the east china sea. Front. Microbiol. 2017, 8, 2133. [CrossRef]

58. Compeau, G.C.; Bartha, R. Sulfate-reducing bacteria: Principal methylators of mercury in anoxic estuarine sediment. Appl. Environ. Microbiol. 1985, 50, 498-502. [CrossRef]

59. Yu, X.; Khan, S.; Khan, A.; Tang, Y.; Nunes, L.M.; Yan, J.; Ye, X.; Li, G. Methyl mercury concentrations in seafood collected from Zhoushan Islands, Zhejiang, China, and their potential health risk for the fishing community: Capsule: Methyl mercury in seafood causes potential health risk. Environ. Int. 2020, 137, 105420. [PubMed]

60. Luther, G.W.; Findlay, A.J.; MacDonald, D.J.; Owings, S.M.; Hanson, T.E.; Beinart, R.A.; Girguis, P.R. Thermodynamics and kinetics of sulfide oxidation by oxygen: A look at inorganically controlled reactions and biologically mediated processes in the environment. Front. Microbiol. 2011, 2, 62. [PubMed]

61. Mehta, P.K. Mechanism of expansion associated with ettringite formation. Cem. Concr. Res. 1973, 3, 1-6.

62. Urquidi-Macdonald, M.; Macdonald, D.D. Modeling mechanisms in biocorrosion. In Understanding Biocorrosion; Elsevier: Amsterdam, The Netherlands, 2014; pp. 243-277.

63. Basista, M.; Weglewski, W. Micromechanical modeling of sulphate corrosion in concrete: Influence of ettringite forming reaction. Theor. Appl. Mech. 2008, 35, 29-52.

64. Dong, J.Q.; Netten, J. Information technology and external search in the open innovation age: New findings from Germany. Technol. Forecast. Soc. Chang. 2017, 120, 223-231.

65. Walker, C.B.; Stolyar, S.S.; Pinel, N.; Yen, H.C.B.; He, Z.; Zhou, J.; Stahl, D.A. Recovery of temperate Desulfovibrio vulgaris bacteriophage using a novel host strain. Environ. Microbiol. 2006, 8, 1950-1959.

66. Eydal, H.S.; Jägevall, S.; Hermansson, M.; Pedersen, K. Bacteriophage lytic to Desulfovibrio aespoeensis isolated from deep groundwater. ISME J. 2009, 3, 1139-1147.

67. Handley, J.; Adams, V.; Akagi, J.M. Morphology of bacteriophage-like particles from Desulfovibrio vulgaris. J. Bacteriol. 1973, 115, 1205.

68. Rapp, B.J.; Wall, J.D. Genetic transfer in Desulfovibrio desulfuricans. Proc. Natl. Acad. Sci. USA 1987, 84, $9128-9130$.

69. Kamimura, K.; Araki, M.U.S. Method for Preventing Biofouling of Surfaces in Contact with Sea Water. Patent No. 4,778,653, 18 October 1988.

70. Kamimura, K.; Araki, M. Isolation and characterization of a bacteriophage lytic for Desulfovibrio salexigens, a salt-requiring, sulfate-reducing bacterium. Appl. Environ. Microbiol. 1989, 55, 645-648.

71. Chibani-Chennoufi, S.; Bruttin, A.; Dillmann, M.L.; Brussow, H. Phage-host interaction: An ecological perspective. J. Bacteriol. 2004, 186, 3677-3686. [CrossRef] [PubMed]

72. Walker, C.B.; Stolyar, S.; Chivian, D.; Pinel, N.; Gabster, J.A.; Dehal, P.S.; Wall, J.D. Contribution of mobile genetic elements to Desulfovibrio vulgaris genome plasticity. Environ. Microbiol. 2009, 11, 2244-2252. [CrossRef] [PubMed]

73. Labrie, S.J.; Samson, J.E.; Moineau, S. Bacteriophage resistance mechanisms. Nat. Rev. Microbiol. 2010, 8, 317-327. [CrossRef]

74. Hanlon, G.W. Bacteriophages: An appraisal of their role in the treatment of bacterial infections. Int. J. Antimicrob. Agents 2007, 30, 118-128. [CrossRef] [PubMed]

75. Destoumieux-Garzón, D.; Duquesne, S.; Peduzzi, J.; Goulard, C.; Desmadril, M.; Letellier, L.; Boulanger, P. The iron-siderophore transporter FhuA is the receptor for the antimicrobial peptide microcin J25: Role of the microcin Val11-Pro16 $\beta$-hairpin region in the recognition mechanism. Biochem. J. 2005, 389, 869-876. [CrossRef]

76. Lu, M.J.; Stierhof, Y.D.; Henning, U. Location and unusual membrane topology of the immunity protein of the Escherichia coli phage T4. J. Virol. 1993, 67, 4905-4913. [CrossRef] 
77. Tock, M.R.; Dryden, D.T. The biology of restriction and anti-restriction. Curr. Opin. Microbiol. 2005, 8, 466-472. [CrossRef]

78. Enning, D.; Garrelfs, J. Corrosion of iron by sulfate-reducing bacteria: New views of an old problem. Appl. Environ. Microbiol. 2014, 80, 1226-1236. [CrossRef]

79. Venzlaff, H.; Enning, D.; Srinivasan, J.; Mayrhofer, K.J.; Hassel, A.W.; Widdel, F.; Stratmann, M. Accelerated cathodic reaction in microbial corrosion of iron due to direct electron uptake by sulfate-reducing bacteria. Corros. Sci. 2013, 66, 88-96. [CrossRef]

80. Von Wolzogen Kühr, C.A.H.; Van der Vlugt, L.S. Aerobic and Anaerobic Iron Corrosion in Water Mains. J. Am. Water Works Assoc. 1953, 45, 33-46. [CrossRef]

81. Dinh, H.T.; Kuever, J.; Mußmann, M.; Hassel, A.W.; Stratmann, M.; Widdel, F. Iron corrosion by novel anaerobic microorganisms. Nature 2004, 427, 829-832. [CrossRef] [PubMed]

82. Flores, G.E.; Bates, S.T.; Caporaso, J.G.; Lauber, C.L.; Leff, J.W.; Knight, R.; Fierer, N. Diversity, distribution and sources of bacteria in residential kitchens. Environ. Microbiol. 2013, 15, 588-596. [CrossRef] [PubMed]

83. Odom, J.M. Industrial and environmental activities of sulfate-reducing bacteria. In The Sulfate-Reducing Bacteria: Contemporary Perspectives; Springer: New York, NY, USA, 1993; pp. 189-210.

84. Kushkevych, I.; Leščanová, O.; Dordević, D.; Jančíková, S.; Hošek, J.; Vítězová, M.; Buňková, L.; Drago, L. The Sulfate-Reducing Microbial Communities and Meta-Analysis of Their Occurrence during Diseases of Small-Large Intestine Axis. J. Clin. Med. 2019, 8, 1656. [CrossRef] [PubMed]

85. Kushkevych, I.; Dordević, D.; Vítězová, M.; Kollár, P. Cross-correlation analysis of the Desulfovibrio growth parameters of intestinal species isolated from people with colitis. Biologia 2018, 73, 1137-1143. [CrossRef]

86. Kushkevych, I.; Dordević, D.; Vítězová, M. Analysis of pH dose-dependent growth of sulfate-reducing bacteria. Open Med. 2019, 14, 66-74. [CrossRef]

87. Langendijk, P.S.; Hanssen, J.T.J.; Van der Hoeven, J.S. Sulfate-Reducing Bacteria in Association with Human Periodontitis. J. Clin. Periodontol. 2000, 27, 943-950. [CrossRef]

88. Langendijk-Genevaux, P.S.; Hanssen, J.T.J.; Van der Hoeven, J.S. Decrease of Sulfate-Reducing Bacteria after Initial Periodontal Treatment. J. Dent. Res. 2001, 80, 1637-1642. [CrossRef]

89. Langendijk-Genevaux, P.S.; Grimm, W.D.; van der Hoeven, J.S. Sulfate-Reducing Bacteria in Relation with Other Potential Periodontal Pathogens. J. Clin. Periodontol. 2001, 28, 1151-1157. [CrossRef]

90. Kotrsová, V.; Kushkevych, I. Possible methods for evaluation of hydrogen sulfide toxicity against lactic acid bacteria. Biointerface Res. Appl. Chem. 2019, 9, 4066-4069.

91. Kushkevych, I.; Dordević, D.; Kollar, P. Analysis of physiological parameters of Desulfovibrio strains from individuals with colitis. Open Life Sci. 2018, 13, 481-488. [CrossRef]

92. Kushkevych, I.; Abdulina, D.; Kováč, J.; Dordević, D.; Vítězová, M.; Iutynska, G.; Rittmann, S.K.M. Adenosine-5'-Phosphosulfateand Sulfite Reductases Activities of Sulfate-Reducing Bacteria from Various Environments. Biomolecules 2020, 10, 921. [CrossRef] [PubMed]

93. Kushkevych, I.; Castro Sangrador, J.; Dordević, D.; Rozehnalová, M.; Černý, M.; Fafula, R.; Vítězová, M.; Rittmann, S.K.M. Evaluation of Physiological Parameters of Intestinal Sulfate-Reducing Bacteria Isolated from Patients Suffering from IBD and Healthy People. J. Clin. Med. 2020, 9, 1920. [CrossRef] [PubMed]

94. Gibson, G.R.; Cummings, J.H.; Macfarlane, G.T. Growth and activities of sulphate-reducing bacteria in gut contents of health subjects and patients with ulcerative colitis. FEMS Microbiol. Ecol. 1991, 86, 103-112. [CrossRef]

95. Zinkevich, V.; Beech, I.B. Screening of sulfate-reducing bacteria in colonoscopy samples from healthy and colitic human gut mucosa. FEMS Microbiol. Ecol. 2000, 34, 147-155. [CrossRef] [PubMed]

96. Fite, A.; Macfarlane, G.T.; Cummings, J.H.; Hopkins, M.J.; Kong, S.C.; Furrie, E.; Macfarlane, S. Identification and quantitation of mucosal and faecal desulfovibrios using real time polymerase chain reaction. Gut 2004, 53, 523-529. [CrossRef]

97. Coutinho, C.M.L.M.; Coutinho-Silva, R.; Zinkevich, V.; Pearce, C.B.; Ojcius, D.M.; Beech, I. Sulphate-reducing bacteria from ulcerative colitis patients induce apoptosis of gastrointestinal epithelial cells. Microb. Pathog. 2017, 112, 126-134. [CrossRef]

98. Pitcher, M.C.; Cummings, J.H. Hydrogen sulphide: A bacterial toxin in ulcerative colitis? Gut 1996, 39, 1-4. [CrossRef]

99. Cooper, C.E.; Brown, G.C. The inhibition of mitochondrial cytochrome oxidase by the gases carbon monoxide, nitric oxide, hydrogen cyanide and hydrogen sulfide: Chemical mechanism and physiological significance. J. Bioenerg. Biomembr. 2008, 40, 533. [CrossRef]

100. Levine, J.; Ellis, C.J.; Fume, J.K.; Springfield, J.; Levitt, M.D. Fecal hydrogen sulfide production in ulcerative colitis. Am. J. Gastroenterol. 1998, 93, 83-87. [CrossRef]

101. Cummings, J.H.; Macfarlane, G.T.; Macfarlane, S. Intestinal Bacteria and Ulcerative Colitis. Curr. Issues Intest. Microbiol. 2003, 4, 9-20.

102. Blachier, F.; Davila, A.M.; Mimoun, S. Luminal sulfide and large intestine mucosa: Friend or foe? Amino Acids 2010, 39, 335-347. [CrossRef] [PubMed]

103. Ijssennagger, N.; van der Meer, R.; van Mil, S.W. Sulfide as a mucus barrier-breaker in inflammatory bowel disease? Trends Mol. Med. 2016, 22, 190-199. [CrossRef] [PubMed]

104. Kronheim, S.; Daniel-Ivad, M.; Duan, Z.; Hwang, S.; Wong, A.I.; Mantel, I.; Nodwell, J.R.; Maxwell, K.L. A chemical defence against phage infection. Nature 2018, 564, 283-286. [CrossRef] [PubMed]

105. Clokie, M.R. Bacterial defence molecules target viral DNA. Nature 2018, 564, 199-200. [CrossRef] [PubMed] 
106. Mori, K.; Kim, H.; Kakegawa, T.; Hanada, S. A Novel Lineage of Sulfate-Reducing Microorganisms: Thermodesulfobiaceae fam. Nov., Thermodesulfobium narugense, Gen. Nov., Sp. Nov., a New Thermophilic Isolate from a Hot Spring. Extremophiles 2003, 7, 283-290. [CrossRef]

107. Vianna, M.E.; Holtgraewe, S.; Seyfarth, I.; Conrads, G.; Horz, H.P. Quantitative Analysis of Three Hydrogenotrophic Microbial Groups, Methanogenic Archaea, Sulfate-Reducing Bacteria, and Acetogenic Bacteria, within Plaque Biofilms Associated with Human Periodontal Disease. J. Bacteriol. 2008, 190, 3779-3785. [CrossRef]

108. Widdel, F.; Pfennig, N. Studies on Dissimilatory Sulfate-Reducing Bacteria That Decompose Fatty Acids. Arch. Microbiol. 1981, 129, 385-400. [CrossRef]

109. Robichaux, M.; Howell, M.; Boopathy, R. Growth and Activities of Sulfate-Reducing and Methanogenic Bacteria in Human Oral Cavity. Curr. Microbiol. 2003, 47, 12-16. [CrossRef]

110. Wallace, J.L.; Motta, J.-P.; Buret, A.G. Hydrogen Sulfide: An Agent of Stability at the Microbiome-Mucosa Interface. Am. J. Physiol. Gastrointest. Liver Physiol. 2018, 314, G143-G149. [CrossRef]

111. Nicholls, P.; Kim, J.K. Sulphide as an Inhibitor and Electron Donor for the Cytochrome c Oxidase System. Can. J. Biochem. 1982, 60, 613-623. [CrossRef]

112. Persson, S. Hydrogen Sulfide and Methyl Mercaptan in Periodontal Pockets. Oral Microbiol. Immunol. 1992, 7, 378-379. [CrossRef] [PubMed]

113. Beerens, H.; Romond, C. Sulfate-Reducing Anaerobic Bacteria in Human Feces. Am. J. Clin. Nutr. 1977, 30, 1770-1776. [CrossRef] [PubMed]

114. Wommack, K.E.; Colwell, R.R. Virioplankton: Viruses in aquatic ecosystems. Microbiol. Mol. Biol. Rev. 2000, 64, 69-114. [CrossRef] [PubMed]

115. Weinbauer, M.G. Ecology of prokaryotic viruses. FEMS Microbiol. Rev. 2004, 28, 127-181. [CrossRef] [PubMed]

116. Mushegian, A.R. Are There 1031 Virus Particles on Earth, or More, or Fewer? J. Bacteriol. 2020, 202, e00052-20. [CrossRef]

117. Little, J.W. Lysogeny, prophage induction, and lysogenic conversion. In Phages; American Society of Microbiology: Washington, DC, USA, 2005; pp. 37-54.

118. Trubl, G.; Hyman, P.; Roux, S.; Abedon, S.T. Coming-of-Age Characterization of Soil Viruses: A User's Guide to Virus Isolation, Detection within Metagenomes, and Viromics. Soil Syst. 2020, 4, 23. [CrossRef]

119. Gong, C. Isolation, Characterization and Application of Bacteriophage to Treat Hydrogen Sulfide Producing Bacteria in Raw Animal Materials Destined for the Rendering Process. Master's Thesis, Clemson University, Clemson, SC, USA, $2010 ;$ p. 1035.

120. Zago, M.; Lanza, B.; Rossetti, L.; Muzzalupo, I.; Carminati, D.; Giraffa, G. Selection of Lactobacillus plantarum strains to use as starters in fermented table olives: Oleuropeinase activity and phage sensitivity. Food Microbiol. 2013, 34, 81-87. [CrossRef]

121. Phumkhachorn, P.; Rattanachaikunsopon, P. Bacteriophage specific to nisin producing—Lactococcus lactis subsp. lactis TFF221, a starter culture in Thai fermented food. Afr. J. Microbiol. Res. 2011, 5, 1203-1210.

122. Szczepanska, A.K.; Hajnowicz, M.S.; Kolakowski, P.; Bardowski, J. Biodiversity of Lactococcus lactis bacteriophages in Polish dairy environment. Acta Biochim. Pol. 2007, 54, 151-158. [CrossRef]

123. Rattanachaikunsopon, P.; Phumkhachorn, P. Bacteriophage $\Phi$ LPN014 infecting Lactobacillus plantarum N014, A potential starter culture for NHAM fermentation. Ann. Exp. Biol. 2014, 2, 1-7.

124. Guttman, B.; Raya, R.; Kutter, E. Basic Phage Biology. Bacteriophages: Biology and Applications; CRC Press: Boca Raton, FL, USA, 2005.

125. Seyedirashti, S.; Wood, C.; Akagi, J.M. Induction and partial purification of bacteriophages from Desulfovibrio vulgaris (Hildenborough) and Desulfovibrio desulfuricans ATCC 13541. Microbiology 1991, 137, 1545-1549. [CrossRef] [PubMed]

126. Seyedirashti, S.; Wood, C.; Akagi, J.M. Molecular characterization of two bacteriophages isolated from Desulfovibrio vulgaris NCIMB 8303 (Hildenborough). Microbiology 1992, 138, 1393-1397. [CrossRef] [PubMed]

127. Housby, J.N.; Mann, N.H. Phage therapy. Drug Discov. Today 2009, 14, 536-540. [CrossRef] [PubMed]

128. Harada, L.K.; Silva, E.C.; Campos, W.F.; Del Fiol, F.S.; Vila, M.; Dą̧rowska, K.; Balcão, V.M. Biotechnological applications of bacteriophages: State of the art. Microbiol. Res. 2018, 212, 38-58. [CrossRef] [PubMed]

129. Farr, R.; Choi, D.S.; Lee, S.W. Phage-based nanomaterials for biomedical applications. Acta Biomater. 2014, 10, 1741-1750. [CrossRef]

130. Adhya, S.; Merril, C.R.; Biswas, B. Therapeutic and prophylactic applications of bacteriophage components in modern medicine. Cold Spring Harbor Perspect. Med. 2014, 4, a012518. [CrossRef]

131. Merril, C.R.; Scholl, D.; Adhya, S.L. The prospect for bacteriophage therapy in Western medicine. Nat. Rev. Drug Discov. 2003, 2, 489-497. [CrossRef]

132. Merril, C.R.; Biswas, B.; Carlton, R.; Jensen, N.C.; Creed, G.J.; Zullo, S.; Adhya, S. Long-circulating bacteriophage as antibacterial agents. Proc. Natl. Acad. Sci. USA 1996, 93, 3188-3192. [CrossRef]

133. Vitiello, C.L.; Merril, C.R.; Adhya, S. An amino acid substitution in a capsid protein enhances phage survival in mouse circulatory system more than a 1000-fold. Virus Res. 2005, 114, 101-103. [CrossRef]

134. Scholl, D.; Rogers, S.; Adhya, S.; Merril, C.R. Bacteriophage K1-5 encodes two different tail fiber proteins, allowing it to infect and replicate on both K1 and K5 strains of Escherichia coli. J. Virol. 2001, 75, 2509-2515. [CrossRef]

135. Carlton, R.M. Phage therapy: Past history and future prospects. Arch. Immunol. Ther. Exp. 1999, 47, $267-274$. 
136. Carlton, R.M.; Noordman, W.H.; Biswas, B.; De Meester, E.D.; Loessner, M.J. Bacteriophage P100 for control of Listeria monocytogenes in foods: Genome sequence, bioinformatic analyses, oral toxicity study, and application. Regul. Toxicol. Pharmacol. 2005, 43, 301-312. [CrossRef] [PubMed]

137. Pirnay, J.P.; Blasdel, B.G.; Bretaudeau, L.; Buckling, A.; Chanishvili, N.; Clark, J.R.; Gabard, J. Quality and safety requirements for sustainable phage therapy products. Pharm. Res. 2015, 32, 2173-2179. [CrossRef] [PubMed]

138. Xu, J.; Kiesel, B.; Kallies, R.; Jiang, F.L.; Liu, Y.; Maskow, T. A fast and reliable method for monitoring of prophage-activating chemicals. Microb. Biotechnol. 2018, 11, 1112-1120. [CrossRef]

139. Xu, D.; Jia, R.; Li, Y.; Gu, T. Advances in the treatment of problematic industrial biofilms. World J. Microbiol. Biotechnol. 2017, 33, 97. [CrossRef]

140. Summer, E.J. Preparation of a phage DNA fragment library for whole genome shotgun sequencing. In Bacteriophages; Humana Press: Totowa, NJ, USA, 2009; pp. 27-46.

141. Summer, E.J.; Liu, M.; Summer, N.S.; Baldwin, D.U.S. Prevention and Remediation of Petroleum Reservoir Souring and Corrosion by Treatment with Virulent Bacteriophage. Patent No. 9,650,272, 16 May 2017.

142. Summer, E.J.; Liu, M.; Gill, J.J.; Grant, M.; Chan-Cortes, T.N.; Ferguson, L.; Orchard, R.C. Genomic and functional analyses of Rhodococcus equi phages ReqiPepy6, ReqiPoco6, ReqiPine5, and ReqiDocB7. Appl. Environ. Microbiol. 2011, 77, 669-683. [CrossRef]

143. Crispim, J.S.; Dias, R.S.; Vidigal, P.M.P.; de Sousa, M.P.; da Silva, C.C.; Santana, M.F.; de Paula, S.O. Screening and characterization of prophages in Desulfovibrio genomes. Sci. Rep. 2018, 8, 9273. [CrossRef] 